\title{
The Reference Librarian Face-to-Face with Reference Management
}

\author{
Lenuța Ursachi \\ Reference librarian \\ Dunărea de Jos University of Galați \\ E-mail lenuta.ursachi@ugal.ro
}

This case study focuses on the trends of reference management as part of the reference services at "Dunarea de Jos" University of Galati in the last 20 years. The institution aims to adopt reference managers such as Zotero, Mendeley or EndNote online in the most common research-related scenarios, whether for the accreditation of an university specialization, the development of a research topic or bibliometric research. Publish or Perish is also explored for the cases of managing citations and research impact analysis.

Keywords: reference librarians; online reference managers; bibliographic research work; academic libraries

\section{Introduction}

The reference department has always been the interface between the library and its users. The information overload and emerging technologies have reshaped the work of the reference librarian (RL) and changes had to be made to meet users expectations in a successful manner. This case study reveals some of the solutions identified by the RL in terms of managing references.

The analysis was focused on various scenarios as a result of day-to-day interaction with library users (Zabel et al. 2010). In particular, the following topics will be considered:

- Does the library website host a list of new entries in library collection from a specific subject?

- How can I manage different types of information sources for my paper?

- How can I make a list of my papers indexed in Scopus or Web of Science?

- Is it possible to import my papers in ORCiD record?

- How can I compare the bibliometric indicators in Google Scholar, Scopus and Web of Science by using a single tool?

- How can I use a specific citation style for my paper?

One of the main responsibilities of RLs is undoubtedly to be helpful and to save user's time (Igbinovia\&Solanke 2015), so they have to face these challenging situations, to improve their competencies and to bring new and relevant services in the library. The trends in the field indicate reference managers as perfect software tools to be explored for the research process. They are the subject of the analysis performed in this article. Although the results of their implementation have been disseminated among undergraduates, doctoral or postdoctoral students and academics within seminars or faculty meetings, most of them still prefer to manage the information in a rudimentary way, by taking notes on pieces of paper or capturing screenshots on PC.

\section{Methodology}

The paper reflects on a few scenarios and brings practical, inexpensive and innovative approaches in terms of reference management. For many years, "Dunărea de Jos" University Library of Galati (DJULG) had no access to electronic tools and that is why the information was traditionally organized through catalogue cards and library catalogues. In the end of the ' $90 \mathrm{~s}$, we have

Revista Română de Biblioteconomie şi Ştiința Informării = Romanian Journal of Library and Information Science ISSN 2559-5490, ISSN-L 1841-1940 • Volume 14 Issue 22018 pp. 46-55 https://doi.org/10.26660/rrbsi.2018.14.2.46

This work is licensed under a Creative Commons Attribution-NonCommercial-NoDerivatives 4.0 International License 
witnessed the library automation and the development of the Internet. The integrated library system and library webpage have become valuable tools for librarians. Later, after 2010, ARTHRA institutional repository and reference management tools (Zotero, Mendeley and Endnote online) have completed the library's portfolio.

In recent years, as literature also shows, RLs are asked quite often for their help when users need to organize citations (Ahmat et al. 2016). Besides this, complex questions have come from the academics concerned about how to manage the information for their annual evaluation (h-index, citations number, ISI or BDI indexed journals, scientific profiles etc.). Online reference managers such as EndNote and Mendeley can easily manage the results retrieved from the well-known scientific databases Web of Science and Scopus. Moreover, these results can be automatically added in ORCiD record or Publish or Perish software by export-import actions and this way researchers can easily populate their scientific profile or compare metrics.

\section{Results}

DJULG has provided traditional reference services until 2000. In most cases, they included quick references about the library collections, services or opening hours, support on how to search information using the traditional library catalogues, research consultation (Marcu 2006, pp. 2324). The reference department has been involved in promoting the latest library acquisitions by editing bibliographic tools: bulletin of titles added in library collections (books or periodicals), list of the books having as authors the university professors, list of foreign books purchased by the library and so on. Until 2000, besides the cataloguer, the RL also had to write catalogue cards for each new title added in library collections which were used after that as reference instruments for the bibliographies or bulletins (edited by using typing machines) (fig. 1, left side).

Scenario no. 1: Does the library website host a list of new entries in library collection from a specific subject?

The automation of the library in 1998 definitely simplified the bibliographic work of the RL. Plans needed to be changed, knowledge to be updated and skills to be improved, in order to face the new technologies and information sources (Wang et al. 2010). The integrated library system reduced the delivery time of bibliographic references (necessary for the accreditation documentation, research topic or bulletins/repertories). The information could be studied in electronic format through e-mail or library webpage (Fig. 1, right side).

2012 has been the reference year for the implementation of information literacy programs at DJULG which transformed the RL into a digital librarian, more confident in online searching, selecting and managing information. One year after the implementation of ARTHRA institutional repository of "Dunărea de Jos" University of Galati, as Bailey (2005) stated, the RL has started to play a significant role in this respect. In return, the institutional repository has been accepted as a tool to submit and promote bibliographies generated for academic purposes (fig. 2).

Besides the library webpage and institutional repository, other attractive tools have been discovered on the "market". They were sources of inspiration for the RL who turned into "technology mediator" according to Howse et al. definition (2006), ready to guide users in online navigation and reference management. 

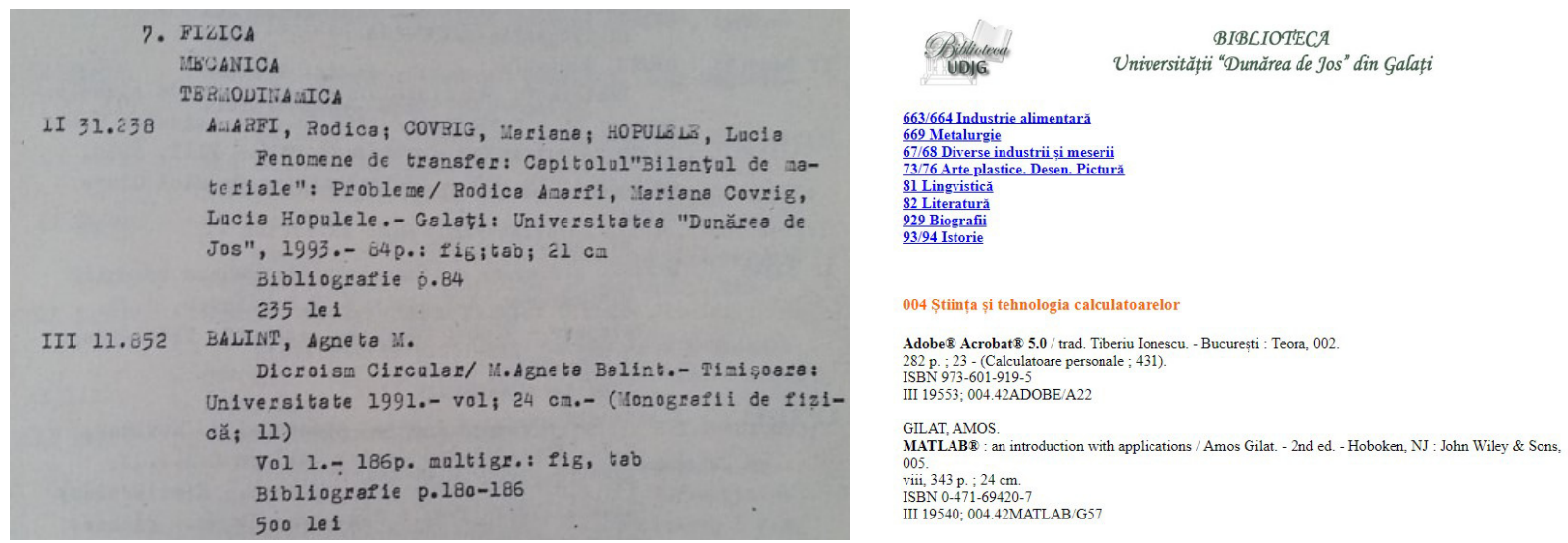

Figure 1. List of new entries in library collection (print and online versions)

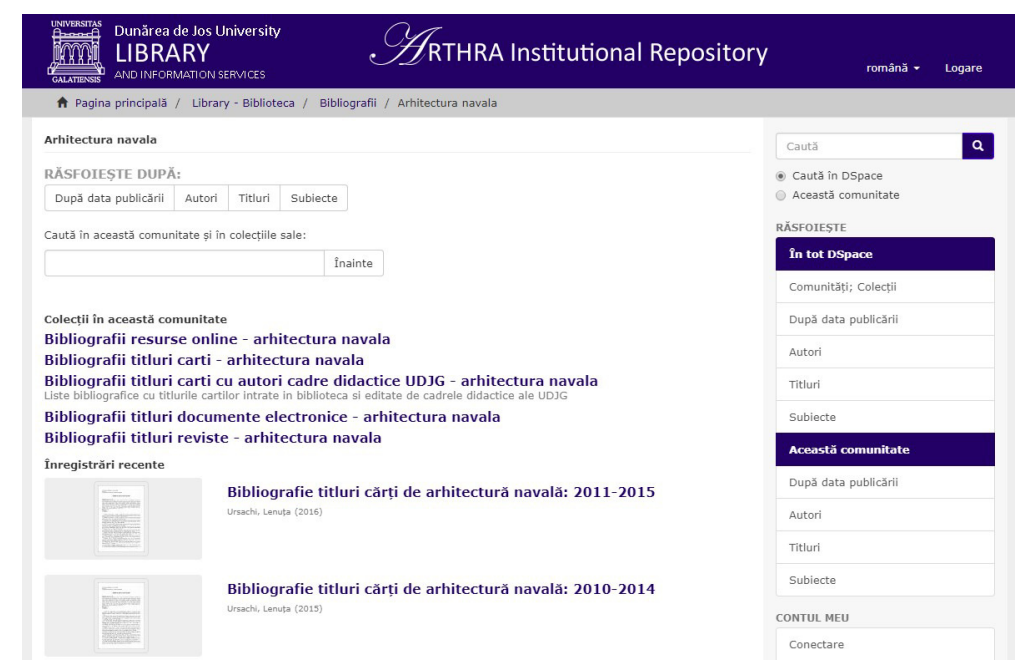

Figure 2. Bibliographies available in ARTHRA institutional repository

Scenario no. 2: How can I manage different type of information sources for my paper?

The research conducted after 2012 indicated the use of the following reference management tools for this scenario: Zotero, Mendeley and EndNote online. These tools are certainly efficient in the stage of collecting and organizing information (Fig. 4) when researchers wanted to manage their print or online resources (retrieved from online library catalogue, online database or academic search engines), as well as in the most discussed stage of citing information. For instance, in order to manage references from an online library catalogue (e.g. by using Zotero), the researcher should follow the steps:

1. access the library online catalogue;

2. conduct a research (e.g. „inginerie electronică și telecomunicaţii” AND cărți AND „TN/2017" - TN/2017 indicates new titles added in library collections during the year 2017)

3. click on Zotero Connector's save button (placed near URL) - it looks like the icon of a folder (indicating a list of results);

4. select the relevant items from the list and then press on OK button (Fig. 3).

Consequently, references will be instantly saved in Zotero library and metadata will be automatically extracted (Fig. 4). 


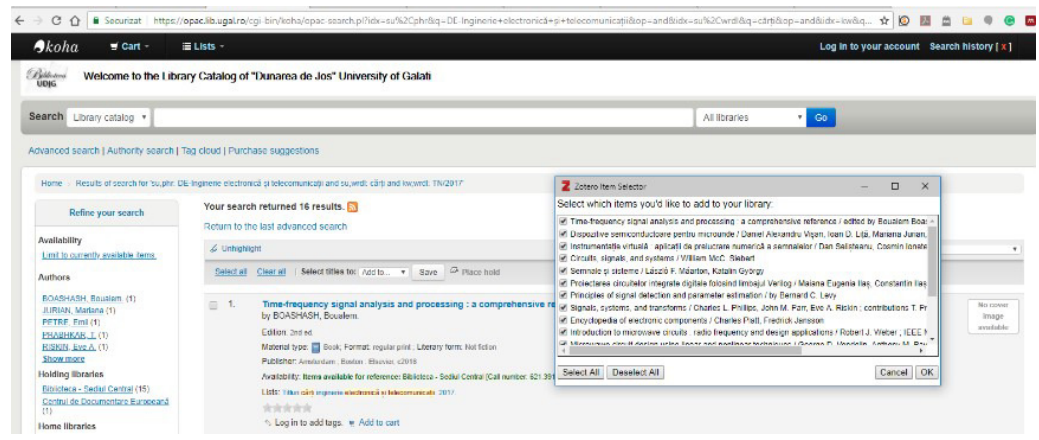

Figure 3. How to save references from Koha library catalogue in Zotero

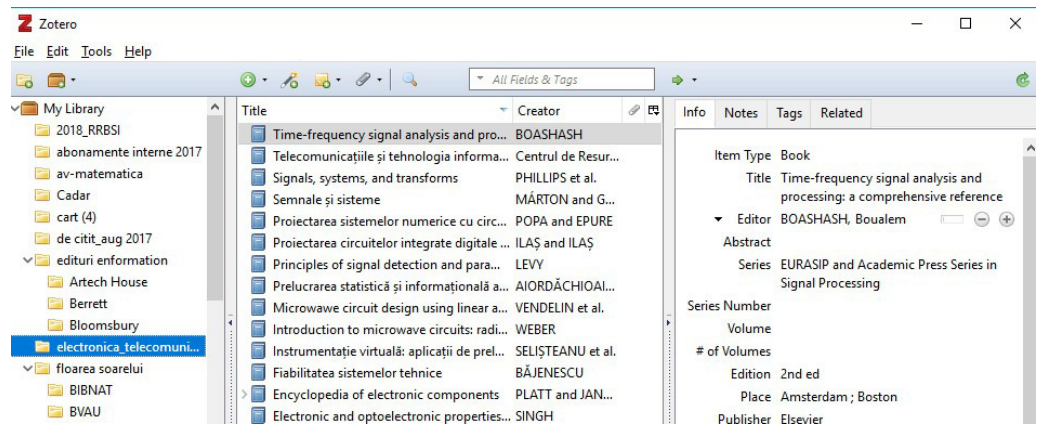

Figure 4. Reference management in Zotero

Scenario no 3: How can I make a list of my papers indexed in Scopus or Web of Science?

Two reference managers are being analyzed for this task, but any of them can be used whether it's for Scopus or Web of Science query. Elsevier has in its portfolio Scopus as abstract and indexing (A\&I) database and Mendeley as reference manager while Clarivate Analytics has similar products in Web of Science and EndNote.

\section{Scopus}

For this scenario, the researcher should follow the steps:

1. access Scopus database;

2. choose „Documents” as search technique;

3. complete the keywords (e.g. Ursachi, L) and choose the criteria from the left side (Author);

4. limit the results to affiliation (Universitatea Dunarea de Jos din Galati);

5. select relevant references from the list and click on Save to Mendeley (Fig. 5) - researcher need to be logged into Mendeley account;

6. view the saved references in the web version of Mendeley Library;

7. synchronize Mendeley Library to get references in the Desktop version (Fig. 6);

8. select the saved references, click right, choose Copy as - Formatted Citation and then apply „Paste” in a blank Word document.

The list of references saved from Scopus should have the format presented below:

1. Ursachi, L., Scutelnicu, E. (2010) 'Welding research journals included in ISI Web of knowledge database', Annals of 'Dunarea de Jos' University of Galati, Fascicle XII, Welding Equipment and Technology, 21.

2. Ursachi, L., Scutelnicu, E. (2013) 'New concepts and techniques implemented by "dunărea de jos" university library of galati', Revista Transilvania, (2), 59-64. 


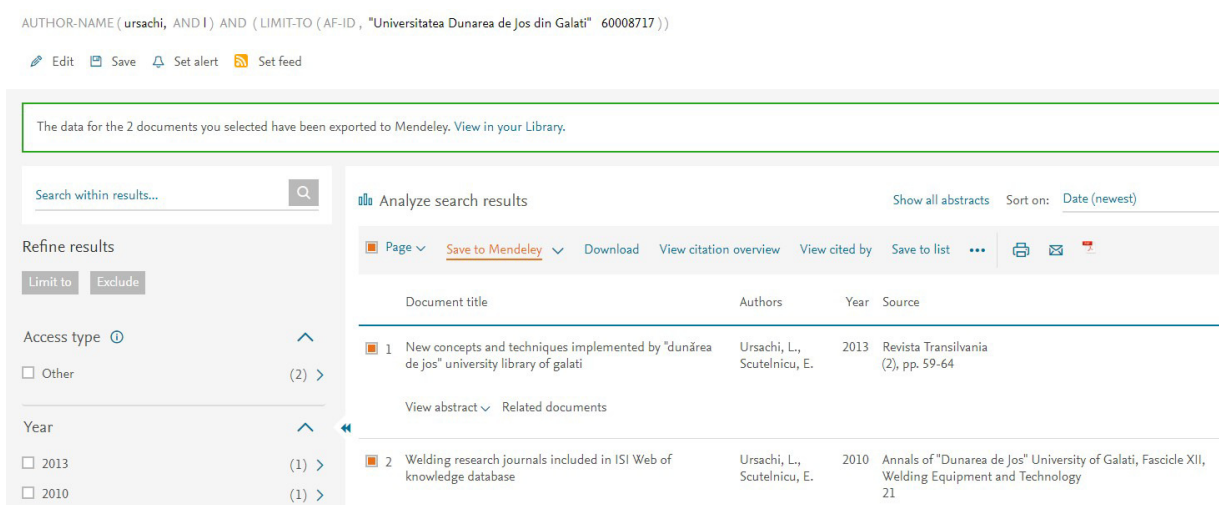

Figure 5. How to save Scopus indexed publications in Mendeley Library

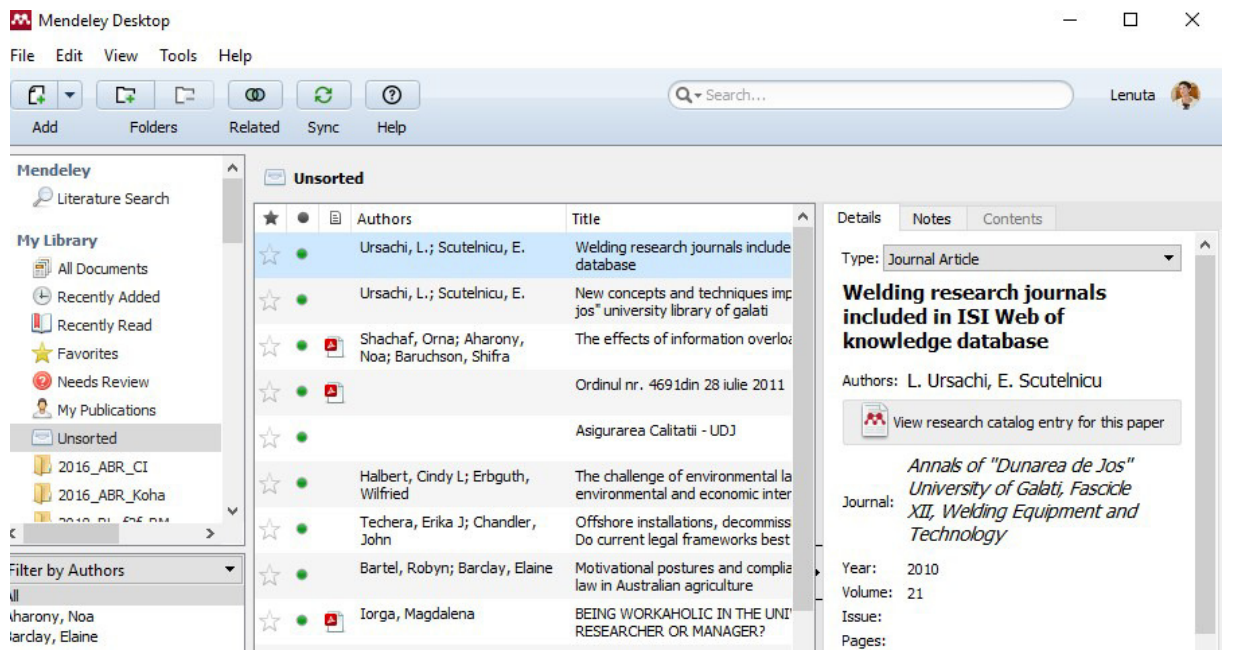

Figure 6. Reference management in Mendeley Desktop

\section{Web of Science}

For the case of a query (e.g. Author search) in Web of Science, the researcher should do the following:

1. access Web of Science database;

2. click on More and then choose Author search option;

3. conduct a search by completing the fields according to the suggested model;

4. choose a research domain and in the end select the affiliation;

5. browse and select the relevant results selection;

6. click on Save to EndNote online;

7. connect to EndNote online account and save the selected references;

8. view the saved results in Unfilled folder (in the left side of the screen);

9. select the results from this folder and add them in a New group or an existing one (Fig. 7).

To create a bibliographic list that should contain these references, the researcher will just click on Format menu, choose Bibliography, select the folder (e.g. Scutelnicu E), select bibliographic style (e.g. ISO 690), select file format (e.g. TXT) and then click on one of the options Save, E-mail or Preview and Print. 
Two references from the bibliographic list are mentioned below:

1. BIRSAN, D. C., C. C. RUSU, E. SCUTELNICU AND L. R. MISTODIE HEAT TRANSFER ANALYSIS IN API X70 STEEL JOINTS PERFORMED BY DOUBLE SUBMERGED ARC WELDING PROCESS. Metalurgia International, 2013a, 18, 62-65.

2. BIRSAN, D. C., E. SCUTELNICU AND D. VISAN. Modeling of Heat Transfer in Pipeline Steel Joint Performed by Submerged Double-Arc Welding Procedure. In A.C. MURARIU ed. Structural Integrity of Welded Structures. 2013b, vol. 814, p. 33-40.

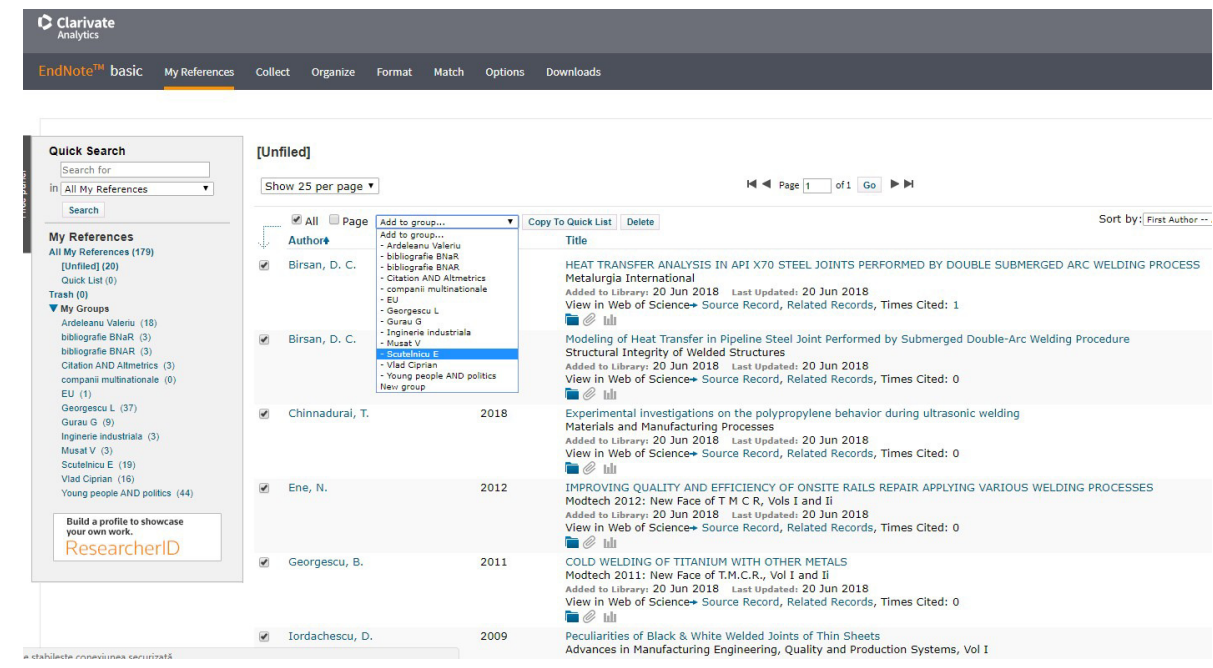

Figure 7. Reference management in EndNote online

Scenario no. 4: Is it possible to import my papers in ORCiD record?

ORCiD is a tool aimed at helping disambiguate author names and integrates with most publisher and A\&I databases. Each researcher has a unique digital identifier and a dedicated webpage which provide access to a set of information usually found in Curriculum Vitae and a list of publications generated through direct import from other systems (e.g. online databases such as Scopus), importexport action via BibTeX or manual addition.

No matter the software tool used for the reference management, the solution stands inthe option of exporting references in a compatible format (e.g. BibTeX). For this scenario, the researcher should follow the steps:

1. access reference manager (Zotero, Mendeley or EndNote online);

2. choose the right collection, folder or group for export;

3. export references contained in that collection/folder/group in BibTeX format;

4. save file in computer;

5. access ORCiD account;

6. go to works section and click on Add works and then choose Import BibTeX (Fig. 8);

7. open file saved in computer and references will be automatically added in ORCiD record.

Scenario no. 5: How can I compare the bibliometric indicators in Google Scholar, Scopus and Web of Science by using a single tool?

Publish or Perish (PoP) is a software application designed for academics to retrieve and analyse citations and might be recommended for this scenario. For this matter, the researcher should collect in PoP the results retrieved in Google Scholar, Scopus and Web of Science. 


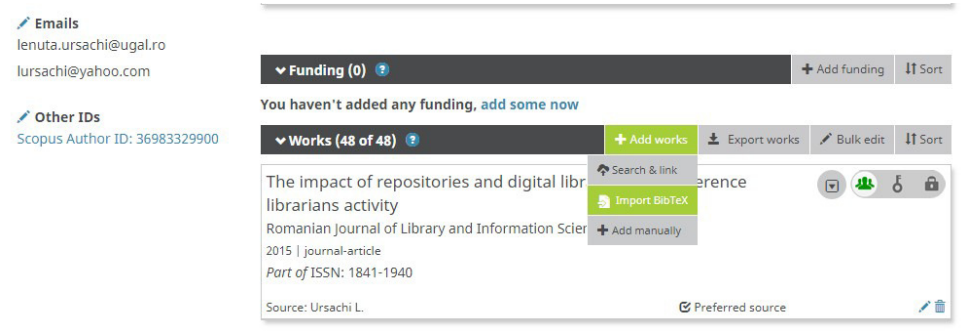

Figure 8. How to import my publications in ORCiD record

\section{Google Scholar query in PoP}

1. access PoP application installed on the computer;

2. select „Google Scholar" button to initiate the query;

3. conduct a search, by completing the field related to author name (e.g. Vlad Ciprian) and then press on Look up button (placed in the right side) and citations will be automatically listed (Fig. 9).

\begin{tabular}{|c|c|c|c|c|c|c|c|}
\hline \multicolumn{8}{|c|}{ Google Scholar query } \\
\hline Authors: & \multicolumn{7}{|l|}{ Vlad Ciprian } \\
\hline \multicolumn{8}{|l|}{ Publication/Journal: } \\
\hline \multicolumn{8}{|l|}{ All of the words: } \\
\hline \multicolumn{8}{|l|}{ Any of the words: } \\
\hline \multicolumn{8}{|l|}{$\begin{array}{l}\text { None of the words: } \\
\text { The phrase: }\end{array}$} \\
\hline \\
\hline Metrics & Help & & Cites & Per year & Rank & Authors & Title \\
\hline $\begin{array}{l}\text { Publication years: } \\
\text { Citation years: }\end{array}$ & $\begin{array}{r}2005-2017 \\
13(2005-2018)\end{array}$ & $\nabla \mathbf{h}$ & 41 & 5.13 & 1 & C Vlad, I Muntean... & Output power maximization of lo... \\
\hline $\begin{array}{l}\text { Papers: } \\
\text { Pars. }\end{array}$ & $\begin{array}{r}37 \\
37\end{array}$ & $\nabla \mathbf{h}$ & 28 & 7.00 & 2 & A ldbaih, K Mokht... & Dramatic response of a BRAF V60... \\
\hline Citations: & 149 & $\nabla \mathbf{h}$ & 14 & 3.50 & 3 & C Vlad, Al Bratcu, I... & Real-time replication of a stand-a... \\
\hline Cites/year: & 11.46 & $\square \mathbf{h}$ & 11 & 1.83 & 5 & C Vlad, MI Sbarcio... & Indirect control of substrate conc... \\
\hline Cites/paper: & 4.03 & $\square \mathbf{h}$ & 10 & 1.67 & 4 & G Casadei, R Teod... & Analysis of dynamic behavior of ... \\
\hline Cites/author: & 48.05 & $\square$ & 5 & 0.83 & 12 & CVlad & Conducerea automată a sistemel... \\
\hline Papers/author: & $\begin{array}{r}13.22 \\
3.49\end{array}$ & $\square$ & 5 & 0.00 & 13 & CVLAD & Contribuții privind conducerea a... \\
\hline $\begin{array}{l}\text { Authors/paper: } \\
\text { h-index: }\end{array}$ & $\begin{array}{r}3.49 \\
5\end{array}$ & $\square$ & 5 & 0.00 & 14 & C VLAD & Contribuții privind conducerea a... \\
\hline g-index: & 11 & $\square$ & 4 & 0.44 & 19 & C Vlad, I Muntean... & Anticipative control of low-powe... \\
\hline hI,norm: & 5 & $\square$ & 3 & 0.75 & 6 & D Floricau, C Vlad & A new five-level rectifier based $0 . .$. \\
\hline hI, annual: & 0.38 & $\square$ & 3 & 0.50 & 7 & C Vlad, S Caraman... & Gain scheduling control of dissol... \\
\hline "Count: & 0 & $\square$ & 3 & 0.38 & 8 & N Badea, C Vlad, ... & Comparative study of energy perf... \\
\hline
\end{tabular}

Figure 9. How to add Google Scholar citations in PoP

\section{Importing Scopus citations in PoP}

1. conduct a search in Scopus (e.g. Author search - Vlad C);

2. export displayed references by selecting Save to Other File Formats;

3. select Method of export - CSV Excel and for Information to export - Citation information

4. save file in computer;

5. access PoP application and click on Import External Data;

6. open the file saved in computer and Scopus citations will be automatically imported (Fig. $10)$.

\section{Importing Web of Science citations}

1. conduct a similar search in Web of Science;

2. export references by selecting Save to Other File Formats;

3. select Record Content - Full record and for File Format - Other Reference Software;

4. save file in computer;

5. access PoP application and click on Import External Data;

6. open the file saved in computer and Web of Science citations will be automatically imported (Fig. 11). 


\begin{tabular}{|c|c|c|c|c|c|}
\hline \multicolumn{6}{|c|}{ Imported external data } \\
\hline Display title: & \multicolumn{5}{|c|}{ scopus.csv [2018-06-21 09:30:47] } \\
\hline Original format: & \multicolumn{5}{|l|}{ Scopus (CSV) } \\
\hline \multirow[t]{2}{*}{ Imported fields: } & $\begin{array}{l}\square \text { Authors } \\
\square \text { Title } \\
\square \text { Publication } \\
\square \text { Publisher }\end{array}$ & $\begin{array}{l}\square \text { Type } \\
\square \text { Year } \\
\square \text { ISSN } \\
\square \text { DOI }\end{array}$ & $\begin{array}{l}\Delta \text { Volume } \\
\text { Issue no. } \\
\text { Start page } \\
\text { End page }\end{array}$ & $\square$ & $\begin{array}{l}\text { Article link } \\
\text { Citation link } \\
\text { Citing references link } \\
\text { Number of citations }\end{array}$ \\
\hline & \multicolumn{5}{|c|}{ Note: Unchecked fields were not available in the imported data. } \\
\hline Metrics & Help & Cites & Per year & Rank & Authors \\
\hline $\begin{array}{l}\text { Publication years: } \\
\text { Citation years: }\end{array}$ & $\begin{array}{r}2005-2018 \\
13(2005-2018)\end{array}$ & $\square \mathbf{h}$ & 3.75 & 19 & C. Vlad, I. Muntea... \\
\hline $\begin{array}{l}\text { Citation years: } \\
\text { Papers: }\end{array}$ & 23 & $\square \mathbf{h}$ & 2.50 & 10 & C. Vlad, A.I. Bratcu... \\
\hline Citations: & 70 & $\square \mathbf{h}$ & 1.33 & 13 & G. Casadei, R. Teo... \\
\hline Cites/year: & 5.38 & $\square \mathbf{h}$ & 1.33 & 17 & C. Vlad, M. Sbarci... \\
\hline Cites/paper: & 3.04 & $\square$ & 1.50 & 6 & C. Vlad, M. Barbu, ... \\
\hline Cites/author: & 17.95 & $\square$ & 0.30 & 21 & C. Vlad, I. Muntea... \\
\hline Papers/author: & 6.15 & $\square$ & 0.50 & 9 & D. Floricau, C. Vlad \\
\hline $\begin{array}{l}\text { Authors/paper: } \\
\text { h-index: }\end{array}$ & $\begin{array}{r}4.00 \\
4\end{array}$ & $\square$ & 0.33 & 16 & C. Vlad, S. Carama... \\
\hline g-index: & 8 & $\square$ & 0.50 & 5 & C. Vlad, M. Barbu, ... \\
\hline hI, norm: & 2 & $\square$ & 0.17 & 14 & C. Vlad, V. Mînzu, ... \\
\hline hI, annual: & 0.15 & $\square$ & 0.13 & 18 & N. Badea, C. Vlad, ... \\
\hline *Count: & 0 & $\bar{n}$ & 0.08 & 23 & G. Gurauiatu. T. M... \\
\hline
\end{tabular}

Figure 10. How to import Scopus citations in PoP

\begin{tabular}{|c|c|c|c|c|c|}
\hline \multicolumn{6}{|c|}{ Imported external data } \\
\hline Display title: & \multicolumn{5}{|c|}{ web of science. txt [2018-06-21 10:05:24] } \\
\hline Original format: & \multicolumn{5}{|c|}{ ISI/WoS (tagged) } \\
\hline \multirow[t]{2}{*}{ Imported fields: } & $\begin{array}{l}\square \text { Authors } \\
\square \text { Title } \\
\square \text { Publication } \\
\square \text { Publisher }\end{array}$ & $\begin{array}{l}\square \text { Type } \\
\square \text { Year } \\
\square \text { ISSN } \\
\square \text { DOI }\end{array}$ & $\begin{array}{l}\square \text { Volume } \\
\square \text { Issue no. } \\
\square \text { Start page } \\
\square \text { End page }\end{array}$ & $\begin{array}{l}\square \\
\square \\
\square \\
\square\end{array}$ & $\begin{array}{l}\text { Article link } \\
\text { Citation link } \\
\text { Citing references link } \\
\text { Number of citations }\end{array}$ \\
\hline & \multicolumn{5}{|c|}{ Note: Unchecked fields were not available in the imported data. } \\
\hline Metrics & Help & Cites & Per year & Rank & Authors \\
\hline $\begin{array}{l}\text { Publication years: } \\
\text { Citation years: }\end{array}$ & $\begin{array}{r}2002-2017 \\
16(2002-2018)\end{array}$ & $\square \mathbf{h}$ & 2.38 & 1 & C Vlad, I Muntean... \\
\hline $\begin{array}{l}\text { Papers: } \\
\text { Patlon years }\end{array}$ & $\begin{array}{r}10(2002-2010) \\
20\end{array}$ & $\square \mathbf{h}$ & 2.00 & 2 & C Vlad, Al Bratcu, I... \\
\hline Citations: & 46 & $\nabla \mathbf{h}$ & 0.38 & 3 & K Hulka, C Vlad, A... \\
\hline Cites/year: & 2.88 & $\square$ & 1.50 & 4 & C Vlad, M Barbu, ... \\
\hline Cites/paper: & 2.30 & $\square$ & 0.50 & 5 & C Vlad, M Sbarcio... \\
\hline Cites/author: & 12.38 & $\square$ & 0.33 & 6 & C Vlad, I Muntean... \\
\hline Papers/author: & $\begin{array}{l}5.55 \\
3.85\end{array}$ & $\square$ & 0.25 & 7 & D Floricau, C Vlad \\
\hline $\begin{array}{l}\text { Authors/paper: } \\
\text { h-index: }\end{array}$ & $\begin{array}{r}3.85 \\
3\end{array}$ & $\square$ & 0.13 & 8 & N Badea, C Vlad, ... \\
\hline g-index: & 6 & $\square$ & 0.10 & 9 & C Vlad, I Muntean... \\
\hline hI, norm: & 2 & $\square$ & 0.08 & 10 & G Gurguiatu, T M... \\
\hline hI, annual: & 0.13 & $\square$ & 0.00 & 11 & SEpure, C Vlad, R ... \\
\hline${ }^{*}$ Count: & 0 & $\square$ & 0.00 & 12 & C Vlad, R Padurar... \\
\hline
\end{tabular}

Figure 11. How to import Web of Science citations in PoP

Scenario no. 6: How can I use a specific citation style for my paper?

If the researcher is looking for a specific citation style (e.g. Materials Today), it is necessary to access the URL https://csl.mendeley.com/about/, search for the citation style (by name or example), edit the closest match (if the citation style couldn't be found) and install or save it in the reference manager.

In Mendeley Desktop, the researcher has the option to import the desired citation style by following the path View menu-Citation styles-Get more styles. In the search box will just type the name of the citation style (e.g. Materials Today), press the button „Use this style” (fig. 12) and then „Install”. The installed citation styles will be retrieved in the left side, Installed. 


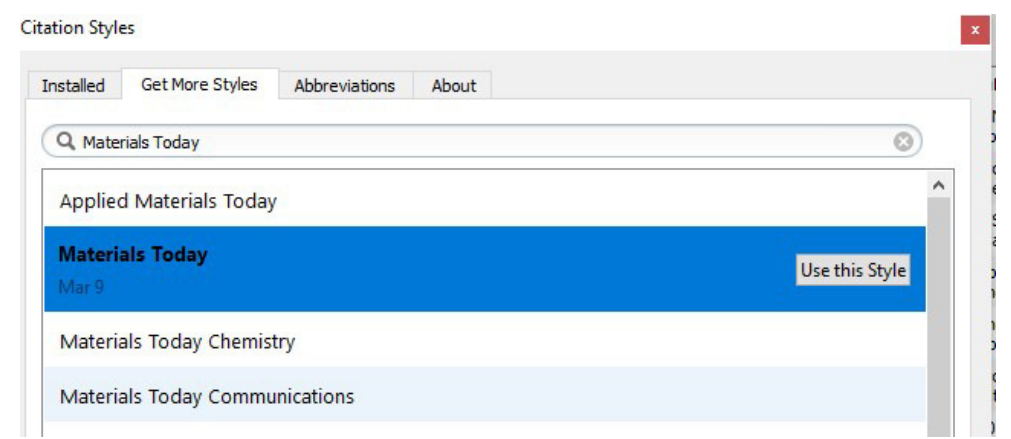

Figure 12. How to import a specific citation style in Mendeley

\section{Discussion and conclusions}

The reference service has been redesigned as new resources and information technologies emerged. The study revealed significant aspects in the evolution of reference management in the last 20 years at DJULG. The Internet has had a major impact on users' life, who became more comfortable with online navigation. Under these circumstances, RLs needed to re-evaluate their behavior, to go ahead and to implement new services to attract library users and to be closer to them.

Reference management is a hot topic nowadays and issues related to plagiarism are very much discussed in debates related to scientific publishing. The RLs proved to be capable of efficiently solving the aspects of reference management and ethical use of information. Training sessions, drop-in sessions and library guides have been included in their agenda. Dedicated software tools have been promoted in order to strengthen the liaison with the faculties and users, to avoid delays in their research work and to demonstrate the multiple qualities of the RLs as genuine managers of information.

The new approach of reference management is not yet entirely embraced by library users. Some of them started to use reference managers, but most of them are still rigid and manage information in a traditional way. Whether we are talking about students who are faced with the problem of managing different types of information or academics who need to gather references for their research impact analysis, this study comes out with a few solutions designed to invite all users to test reference managers.

\section{Acknowledgements}

I would like to thank Mrs. Cristina Alina Huidiu for her support in this case study.

\section{References}

Ahmat, M.A., Jaafar, C.R.C. and Azmi, N.A. (2016) The Transformation of Reference Services in Hamzah Sendut Library, Universiti Sains Malaysia, Procedia-Social and Behavioral Sciences, 224 (6) pp. 6-13, available: https://doi.org/10.1016/j.sbspro.2016.05.392 [accessed 18 June 2018].

Bailey, C.W. (2005) The role of reference librarians in institutional repositories, Reference Services Review, 33(3) pp. 259-267, available: https://doi.org/10.1108/00907320510611294 [accessed 18 June 2018].

Howse, D.K., Bracke, P.J. and Keim, S.M. (2006) Technology mediator: a new role for the reference librarian?, Biomedical Digital Libraries, 3(1), available: https://doi.org/10.1186/17425581-3-10 [accessed 18 June 2018]. 
Igbinovia, M.O. and Solanke, E.O. (2015) Shining a light on the reference librarian role as reference services adapt to users' needs [online], available: https://libraryconnect.elsevier.com/ sites/default/files/LCN_Igbinovia_Solanke_June-30-2015.pdf [accessed 18 June 2018].

Marcu, A. (2006) Noi tendințe în serviciile de referințe din biblioteci [New trends of library reference services], București: Asociația Bibliotecarilor din Învățământ din România.

Wang, H., Tang, Y. and Knight, C. (2010) Contemporary Development of Academic Reference Librarianship in the United States: A 44-Year Content Analysis, The Journal of Academic Librarianship, 36(6) pp. 489-494, available: https://doi.org/10.1016/j.acalib.2010.08.004 [accessed 18 June 2018].

Zabel, D. et al. (2010) The Role of the Academic Reference Librarian in the Learning Commons, Reference \& User Services Quarterly, 50(2) pp. 108-113, available: https://doi.org/10.5860/ rusq.50n2.108 [accessed 18 June 2018]. 